\title{
The Greek Religious Education: \\ From Religion Tradition to Religion Innovation
}

\author{
Karamouzis Polikarpos (Corresponding author) \\ Assistant Professor University of the Aegean, Department of Primary Education \\ 1 Dimokratias, Rhodes, 85100, Greece
}

Tel: 30-2241-099-228Ｅ-mail: pkaram@rhodes.aegean.gr

Received: June 25, 2014 Accepted: July 8, 2014 Published: July 23, 2014

doi:10.5296/jet.v1i2.5862 URL: http://dx.doi.org/10.5296/jet.v1i2.5862

\begin{abstract}
The Orthodox religious tradition constituted an important element of Greek religious education for many years. The existence of innovations in the new Program proposed by the Ministry of Education and the effort for a complete form of religious education, compose the outline of this new effort. Even if certain practical questions have been discussed further, the undertaking is very serious, and perhaps for the first time it can be considered as a scientific approach based on theoretical conditions and instructive objectives. Although religions are well-structured systems, which reproduce themselves through traditional elements such as myths, sacred narratives, religious practices and national identities, their presence in school complements the knowledge of the students. The new program of religious study attempts to give emphasis to renewal, with the introduction of other religions, without cancelling Greek Orthodox religious tradition.
\end{abstract}

Keywords: religious education, innovation, tradition, school, teachers, curriculum

\section{Religion Innovation and Orthodox Christian Tradition}

The definition of innovation is related to concepts like change and continuity. Especially when we talk about the innovation of religion, this term is involved with another term that is the religious tradition. The authors of a recently edited book wonder: "Does innovation mean change and/or renewal? How are they different? Is innovation the opposite of tradition or can innovation also be a part of tradition? What do we mean by tradition?" (Stauning-Willert, \& Molokotos-Liederman, 2012, p. 6). If religion is a social construct, which is connected with the culture, although that includes a powerful core of faith, religion can change. The innovation is related to change and for this reason has characteristics that can be estimated, but each change cannot be an innovation. Innovation is relative to the design and the 
implementation of a new idea or a new product, which is created to be adopted or to be consumed as something innovative or as something new. In this sense, the innovation requires conscious effort of the new configuration, which to a certain extent differs from the old one. An online prayer e.g. designed to be used by cyber-religious is an innovation because it requires construction of expertise and the traditional techniques for prayer, from which the new concept of prayer differs to a certain degree from the old concept and presupposes the existence of consumers of this product, i.e. people that are willing to adopt the new product and to use it as such. In each case the innovation is related with the social features of groups that will manage its content. These groups can be the creators of innovation or consumers or both. If the innovation adds value to the product's development, an idea or a behavior directly depends on the social and cultural characteristics of groups that manage the product, that innovation requires assessment criteria of its content. The process of innovation's diffusion is defined "as the (1) acceptance, (2) over time, (3) of some specific item-an idea or practice, (4) by individuals, groups or other adopting units, linked to (5) specific channels of communication, (6) to a social structure, and (7) to a given system of values, or culture". (Katz, Levin, \& Hamilton, 1963, p. 237)

In the Orthodox tradition the planning of innovation is not a priority. Every time that something was understood as an innovative, like civil marriage, the non-inclusion of religion on political identities cards, the change of religious education, the change of religious oath, etc., the religious tradition opposes it. On the contrary, what we can observe is that on one hand there are those who support the change even in the Orthodox tradition and on the other hand, there are those who stand with skepticism towards change. Both sides make their arguments through religion tradition. It is true that in the Greek society the Orthodox Christian tradition has identified largely the cultural identity of the Greek people. In some cases, the religion identity identified political identity as well, while the structures of political power were connected with religious power structures. It should be noted that the obsession with religious tradition can, for certain groups, be understood as an innovation.

T. Willert and L. Linderman developed an initial typology of five types of Orthodox religion innovation: "1) The first type of innovation is a purist innovation that is promoted by actors who claim that the innovation is in fact a return to a more authentic tradition which has been neglected or rejected by the existing 'tradition'. The arguments in favour of such a type of innovation are drawn from sources that are said to represent an 'authentic' and 'purer' tradition. Despite the adherence to traditional sources, the proposed changes represent innovations because in the historical and geographical context they are a deviation from a dominant form of tradition... 2) A second type of innovation is a strategic innovation that includes negotiations over innovation and tradition relating to the loss or retention of privileges and struggles over power and influence... 3) The third type of innovation has to do with innovations that happen due to specific external circumstances. Therefore, this type can be referred to an adapting innovation that takes place as an adaptation to changes in the social, political or physical environment. The innovation of this type could also take place out of necessity; yet even in cases of necessity there is always a choice as to the degree and form of innovation to be made... 4) Another type of innovation is one that is not intended, i.e. an 
unintentional innovation. This kind of innovation is the result of religious practice or thought taking inspiration from external sources without seeing this as a conflict with tradition... 5) Finally, another type of innovation is one that relates to some form of spiritual or personal development, namely an emancipatory innovation, in which the goal of new ways of thinking and practicing the religion constitutes a form of emancipation from earlier restrictive forms". (Stauning-Willert, \& Molokotos-Liederman, 2012, pp. 9-11).

For these reasons we understand that innovation in the Orthodox tradition is complex and multifaceted and interpreted differently by groups related to it. It is also understood that the innovation in any form can be related with the religious tradition.

\section{Religion Education, Orthodox Christian Tradition and Innovation}

The lesson of religious education in the Curricula of Greek education exists since the foundation of the New Greek State. The character of the lesson was oriented from the beginning towards the Orthodox Christian religion, which with the Greek language both are connected with the cultural identity of the Greek people. In the Greek case, the establishment by the Greek State of an official Greek Church responsible for public worship and religious education of the people formed the operating framework of the religious lesson. The purpose of the lesson of religious education was for several years the "formation of children's ethics". The lesson also served a political purpose, connected with the formation of national identity, but also the character of the Greek citizen. These features also serve the dominant political ideology, while they form the content of a conservative school education. The "Hellenic-Christian culture" is projected for many years as a dominant political and religious ideology. But the content of this ideology was used very differently from time to time. It is no occasional, that the content of the lesson of religious education expresses the views of many groups, such as the representatives of the Church, theologian professors, religious organizations, the Ministry of Education, etc. (Karamouzis, 2009).

The latest decades although this lesson had clearly both: a catechetical character, it also developed a gnoselogical one. In the textbooks (primary and secondary education) written from 2003 to 2006 and accompanied - for the first time - by teachers' books, religious material is approached in a spirit of dialogue and freedom, without fanaticism or bigotry. In this context the new curriculum in religious education was developed in 2011 and was connected with the new program for the "New School". The authors of the curriculum emphasize the necessity of the new program: "From the beginning of the 21 st century, international developments confirm that religious education is recognized as a necessary condition for the multifaceted and comprehensive education of students. Awareness of the risks arising from religious isolation but also by a variety of political or ideological uses of religion leads to the need for religious values to become areas of dialogue, contact and peaceful coexistence of people, regardless of their religious and political beliefs and their differences. In this way, the religions can help to resolve conflicts and create a modern multicultural society". (Greek Ministry of Education, 2011, pp. 10-11). Religious education maintains the knowledge and pedagogical character that it has had up to now, but opened doors to the Christian traditions of Europe and the other religions. The lesson is structured in 


\section{Macrothink

three concentric circles. The first one focuses on the tradition of the Orthodox Christian Church, as it was lived and was reflected in monuments of the local culture. The second cycle is concerned with the most important Christian traditions found in Europe and more generally in the world, other than orthodoxy, such as Catholicism and Protestantism, with their main and basic confessions. The third circle includes the most important religions and in particular those that interest Greek society more, namely the monotheistic traditions of Judaism and Islam, and other religions that have an increased interest (Figure 1).

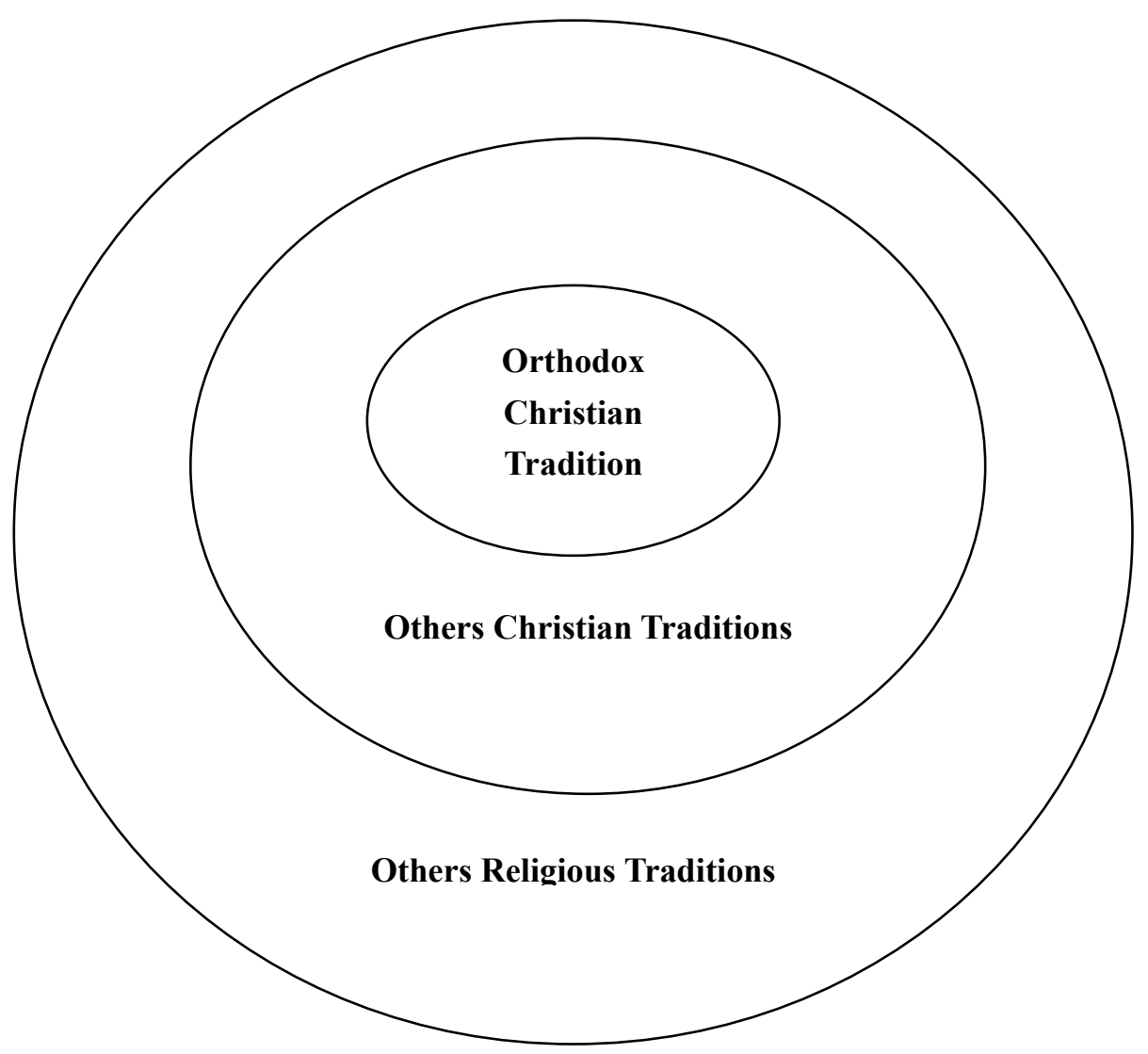

Figure 1. New Curriculum of Religious Education

The approach of religious knowledge in the new analytical curriculum is based on three levels: A. The level of empirical approach. Students learn the various components that make up the religious knowledge, such as the religious language and symbolic codes of religions. B. The level of interpretative approach. Students learn how religions influence personal and social organization of people's lives, but also the relations among people belonging to different religions or those who decided not to belong to any religion. C. The level of critical approach. Students are helped to shape their own opinion for the role of religions. This will be done only when the students understand the actual characteristics of religions, without stereotypes and prejudices. (Greek Ministry of Education, 2011, pp. 20-21). The creation of the new curriculum in religious education is an innovation because it has all the features of 
innovation. The curriculum was designed and the goals are distinctive. The curriculum differentiated from the old curriculum; however, the old curriculum is not entirely rejected. It takes into account the new social, cultural and learning needs and addresses the school community. (Giagkazoglou, 2013). Although the studies programme is based on the Orthodox Christian tradition, it is not limited to this. Tradition is understood more as renewal rather than as a return to the past.

\section{The Reactions in the Innovation}

Reactions to the new curriculum in religious education focused on the character of the lesson. Theological circles and religious organizations have expressed negative opinions about the change in the lesson. The focus of criticism was on the possibility of altering the Greek religious tradition. Specific criticism focused on: 1) the perception that the lesson will be converted from Orthodox Christian to multi-religious, 2) the denial of the religious beliefs of the students in favor of a general knowledge of religions, with the introduction of multicultural theology, 3) the denial of the symbol of faith of Orthodox students, 4) the absence of Orthodox theology with the view of the conciliative role of all religions, 5) the absence of basic concepts and rituals of Orthodox Christian tradition, 6) the view of religious knowledge which replaces the creation of religious faith to the students, 7) the presence of "religious literacy" which focuses on logic because it cannot be linked to the Orthodox Christian tradition, in which faith is foremost and logic follows, 8) the lack of respect to of the religion of the students majority. Religious pluralism cannot be a criterion for determining an educational programme. In the difficult times that Greece is experiencing, a fundamental change is taking place and an overthrow of religious education is taking place. 9) the view of perception that religious literacy does not develop religious awareness among students, but confusion, doubt and relativism as to their own and each other's religiosity, 10) the view that there is non-conformity of the contents of the Curriculum and the level of understanding of the students, (11) It is also supported that the study of other religions should take place after the experiential and empirical development of the students' religion. 12) Teachers who will teach the lesson of religious education should have obtained Orthodox Christian education. (Committee of Experts for the Creation of New Curriculum, 2013). The religious tradition for this group has defensive characteristics towards any change, which is introduced from abroad. This group presents Greek-Christian education and seeks to preserve the existing structure of the course, which connects with the dominant religion. Faith and participation in worship must precede religious knowledge. For this reason, only one religion is displayed and the teacher must be a member of this religion.

The debate that has opened in the Greek society is done in the context of/according to the Orthodox Christian tradition. One side believes that the Orthodox religious tradition should be reproduced in a one-dimensional way, while the other argues that religious tradition can be understood through religious diversity. Both sides consist of theologians with Orthodox theological education, which they have obtained in Greek Faculties of Theology. The Theological Faculties of Greek universities consider that: 1) the lesson of religious education must include elements of Orthodox Christianity because it is the tradition of the Greece, but also study other religions. 2) The lesson of religious education is linked to scientific 
knowledge provided in the theological faculties and lessons such as theology, pedagogy, psychology, and sociology. 3) The lesson of religious education must have a mandatory character. 4) The lesson of religious education must be taught by graduates of theological faculties. 5) The lesson of religious education provides knowledge and is not identified as Catechism. Catechism is Church's work. 6) The lesson of religious education is not intended to form Christian behaviour and personal piety but helps students to cultivate the values and attitudes of life. For the theological faculties, the tradition is linked with knowledge and scientific study and teaching of religious education (Aristoteleio University of Thessaloniki, Faculty of Theology, Decision 15.5.2013).

A significant group that very often expresses its perceptions about issues of religious education is the official Church of Greece. The perceptions of the official Greek Orthodox Church about religious education course are associated with State-Church relations. (Karamouzis, 2008) Traditionally, the Greek Orthodox Church was related to the religious education of the Greek people, while the religious education of young people was a solemn obligation of the Greek State and especially of the Ministry of Education. However, the Greek society does not have the characteristics of a homogenised social construction, as this was done in the past. For some representatives of the Greek Orthodox Church this is a challenge. The question key is: What is the public role of the Greek Church today? The answer given by representatives of the Church is that the role of the Greek Orthodox Church can be neither defensive nor offensive in new social developments. For this reason, issues such as a) the legal status of the relations of Church and State, b) the use of church property, c) the lesson of religious education, and d) the use of religious symbols represent elements that are at the forefront of discussions. Especially for the religious education the following concepts are highlighted: a) creating a lesson for all children, regardless of origin, identity, beliefs, etc. b) creating the course that is taught by trained teachers, theologians from the theological faculties, c) adapting the nature of the content of the course to the new data, but without radical and brutal cut from the core of the Orthodox Christian tradition. (Georgakopoulos, 2013)

The official Greek Church expressed its opinion about the subject of religious education and new curriculum via these indications: 1) The lesson must maintain its cognitive and pedagogical character. 2) The lesson must be a model of life and culture. 3) The focus of the lesson must be the Greek-Orthodox tradition of Greece and its culture. 4) Tradition is connected with the knowledge of religious faith, of religious worship, of religious life, of religious art and culture. 5) The lesson mast be distributed into three concentric circles: a) Orthodox Christian tradition, b) other major Christian traditions, Roman Catholic, Protestants c) other great religious traditions, such as Islam, Judaism, Hinduism, Buddhism, etc., 6) the lesson must retain its name, 7) the lesson must have mandatory weekly teaching, 8) the appointment of teacher of religious education must have the permission of the local bishop. (Holy Synod of Greek Church, 2012) 


\section{The Legal Status of Religious Education and the Development of Religious Consciousness}

The discussion about the new curriculum was expanded towards legal features of the course. The article 16, 2 of the Greek Constitution provides the cultivation and development of "religious conscience" of students in public education. However, in accordance with the article 13, 1, "the freedom of religious conscience is inviolable" and "Every known religion is free ..." Students or their parents can request to be exempt from religious education if they wish. Students can request exemption from religious education if they are of another religion, are the heterodox and if they pose a serious reasons dealing with religious conscience. With a clarifying circular in 2008, the Ministry of education stated that: "for parents of minor pupils or pupils themselves, if they are adults, who for reasons of conscience do not wish to attend the class of religious, it is not necessary to justify a refusal in the application required" (Ministry of Education, 2008). This decision opened the way for the course of religious education in public school to become optional, for those students and their parents who prefer so, simply referring to reasons of conscience. The abuse of this right by some students, particularly by those who belong to the last classes of high school, although they were not heterodox or did not have another religion, but were exempt from religious education lesson because they have so many other lessons to study, led the Ministry of education in 2010 to highlight: a) that it was a mandatory course, b) that the possibility of exemption from the lesson only referred to students that were heterodox or of another religion. Any other exemption, according to the Ministry of education violates the principle of equal treatment of pupils and equal effort to obtain the baccalaureate (Ministry of Education, 2010).

The lesson of religious education, as it is taught until now, creates confusion which arises from the legal framework of the lesson. The legal frameworks of the lesson create a mandatory nature of the lesson, on one hand, while on the other hand it allows for an exemption from the lesson for those who claim "religious conscience". At the same time, the Constitution obliges the school to form the content of "religious conscience" of students. These contradictions arise from a general assumption, according to which the lesson of religious education is closely oriented to the perceptions of the dominant religion. Furthermore, what is the meaning of the exemption of heterodoxies and students of other religions? Towards the same direction, contradiction continues, according to which, on the one hand, the lesson of religious education and the public school form the "religious conscience" of students, while on the other hand this feature is lifted when for the same reasons i.e. of "religious conscience", someone can choose not to participate in religious education lessons. In this way, the lesson is degraded and the institutional character of the school for the formation of "religious conscience" of students is canceled. Of course, a lesson in catechism in the doctrines of a dominant religion may not be acceptable by all and in particular by those who belong to different religious traditions or do not belong to any religion. We note that those who react to any change in the curriculum of religious education support the traditional character of the lesson and consider that "religious conscience" is developed with the inclusion of someone in a religious group or community. Membership is the reproduction of specific concepts, which act as inviolable rules. So, they agree with the 
exemption from the lesson for all those who do not belong to the Orthodox Christian tradition, as long as the lesson continues to have a catechetical character. The consequences of such an evolution would be to strengthen religious unilateralism. Perhaps the lesson of religious education may become optional and may be attended only by the Orthodox students. The other students can either abstain or they can seek to introduce different religious lessons in order to reinforce the different religious beliefs.

But the privilege of studying religion isn't only of a member of a particular religious group, but also for others, even those who do not belong to any religion. Everyone is obliged to study in school, through a critical thinking, the complex roles of religions, particularly as cultural constructions. For this reason "religious consciousness" does not develop automatically by the inclusion of someone in a religious community, nor with the maintenance of a particular religious belief and tradition, but primarily through the dialectic relationship that develops between people through forms of understanding and the explanation of the world, through the logical interpretation of nature, of man, of God or the gods of a particular society. Essentially, the "religious conscience" is not independent of the worldview approach that the free man chooses to adopt, through the social environment in which he lives and moves. (Paparizos, 2011. p.499).

The emergence of "religious conscience" is not a case arising from religious integration or from religious manipulation. Rather it is a case araising through the logical interpretation of religion. Otherwise, people just fall into a religious community without ever having to ask for the deep causes of this integration, without ever having to ask themselves why are members of that religious tradition and not another. These people simply have a religious identity. They are Muslims, Christians, Buddhists, Hindus, etc. not because they wanted to, but because they were born in such religious communities. In religious communities people more often pass without thinking the right to define the communities for themselves, the content of religious truth, regardless of their own logic.

For this reason, the term "religious conscience" has a different content when it is used from the perspective of religions and a different content when is used on the side of school religious education. In the first case, the emphasis is on religious membership, while in the second the knowledge of religions. It becomes so clear that the formation of religious consciousness is not purely a religious affair, but mainly a scientific case of dealing with issues relating to religions, such as what school education does. This does not cancel religious tradition. In contrast, it is recognized to the extent that it is interpreted as a carrier of cultural meaning, which has concrete results for the people of society that nurtures it. Quite rightly, in our view, the legislature gave the school the right of the development of religious consciousness of the students, since only the school can objectively manage the content of religious knowledge of its students in away free from bias and fanaticism. The acquaintance with Orthodox Christian tradition can be realised effectively only through the understanding of other religious traditions. Moreover, we must not forget that self - understanding, that is to a certain extent implemented, takes place only through hetero - understanding. The new curriculum seeks to create this dialectic relationship of local religious tradition with the traditions of other religions by giving an extra criterion for understanding the way that 
students seek to develop their knowledge and for issues relating to religious cultures of other people. This is not just one request only of those who are involved in the themes of religious education at the level of expert, but it is also a demand of wider social groups. Recently in quantitative research, that we did among 1009 student teachers, who will teach the lesson of religious education in primary education, we found out that the majority of them want the obligatory nature of the lesson to remain, but the lesson needs to change in respect to content and purposes. It is worth noting that these perceptions are supported by the majority of the future teachers who stated that they belong to the Orthodox Christian tradition (Karamouzis \& Athanasiadis, 2011, p. 142).

\section{The Religion Tradition and the New Social Networks of Religious Education}

All groups that are mentioned above are related in one way or another with religious tradition, via which they convey different characteristics. We could discern elements such as: a) the characteristics of the learning of tradition, (b) the religious characteristics, c) the national characteristics, d) the pedagogical features, e) the moral features, etc. However, the religious education may be, for certain groups, an area of political control of the issues associated with the dominant religious perception. The groups that connect religious education with religious tradition through an exclusive and univocal relationship or consider themselves defenders of this relationship, form the content of tradition with their own presence within the social space. It is not the religious tradition that serves as a creative understanding of different, but as a promotion of their own perceptions. In this case, the lesson of religious education is restricted because it lacks the fundamental elements of the social presence of religion, namely communication with diversity. Those that have completely different perceptions of religious tradition are those who have prepared the new curriculum. They do not degrade religious education to the role of a servant of religious tradition, but instead they use creative elements of Greek religious tradition in order to understand different religions. Especially, they consider that enlargement of the content and objectives of the Greek school religious education, not only will not alter the Greek religious tradition, but instead it will give the opportunity for religious tradition to be presented without fanaticism, defeatism and intolerance.

The need for incorporation of religious lessons in the curricula of compulsory depends on the aims of education policy in its entirety. The structures of the content of a lesson of religious education, which must take account the specific objectives, raises crucial questions about the characteristics of the course. If the criterion of social cohesion is considered more important in a multi-faith society, what would happen if the same criterion is extremely crucial for a society which is not multi-faith? In other words the question is the following: is the differentiating of the content of religious education from region to region a legitimate way to differentiate the educational objectives or should some goals be common? With what criteria will this be done every time?

The practical interest for religious education today is not independent of the political characteristics that shape each society. In the same way, the presence of religious tradition is connected with these features. We must not forget that the religious education can incorporate 
those features of religion, as its role in the construction of community and social identity, as well as its institutional influence on social cohesion. However, if social cohesion is a timeless pursuit of all societies, having in the past created and used corresponding social and religious networks for social and political control of diversity, including the school, today the integration of diversity requires a different understanding of social cohesion policy. So insisting on showing a one-dimensional religious tradition that fails to recognize and to accept religious diversity and coexist with it, cannot be the content of an educational policy that supports the social section. If, for instance, the knowledge of religion in public school was connected exclusively with the cultural characteristics of a homogeneous society, in which religion played a dominant role, today new challenges are redefining the content of religious education in schools under specific political objectives. In other words, if the needs for social cohesion went by in the past through a certain cultural construction in which religion played a leading role, now the political cohesion of extended social groups is sought through otherness, without meaning that cultural and religious specifications have lost their social reports. All the negative characteristics of globalization (loss of traditional values, economic crisis and corruption) encourage a new interest for the character of spirituality as an essential feature in human beings and their societies. These figures bring to the forefront of discussions the role of religious education and school, not only for religious people, but also for non-religious. Clive Beck notes that spirituality includes values such as "Awareness, Integration, Wonder, Gratitude, Hope, Courage, Energy, Detachment", which the school must cultivate for all students, whether they belong to a particular religious environments or not (Beck, 1986, 151-153).

The formulation of a complete programme of study in religious education is not a simple affair. It must take into account many individual targets, which cover a wide range of management of social reality. In this sense, a religious education that determines its content only in order to promote tolerance or social cohesion, independent of knowledge of religious language and symbolic patterns of religions, but also of the interpretative approaches the religious understanding, can lead to misunderstandings. We must bear in mind the fact that the students are invited to reinterpret the fact of religion through the educational process by creating their own social networks, which include common and different cultural values. The Council of Europe notes: «It must be said, however, that some are now talking of Europe not as a post-Christian society but as a post-secular society. The reasons for this are themselves complex and debateable, but no one can doubt that religion still is a cultural phenomenon (or set of phenomena) that is of significance in all European societies. This concept also allows the scope of religion to include humanist viewpoints or other philosophical and moral convictions. This is particularly important in Europe where there are many people (and children) who do not have traditional religious, theistic beliefs, but yet have beliefs and values».

The religious tradition contributes to the formation and maintenance of the content of an identity, which in any case may not be uniform. It can also be an instrument that creates social networks that facilitate the achievement of specific human desires. If until now, the religious tradition helped local social networks to survive, the coexistence of different 
religious traditions today is considered as a prerequisite for the cultivation of modern intercultural social networks. The religious contribution is necessary in order for the items of coexistence of peoples and their cultures to be projected. The aim is no longer the hegemonic presence of a culture or tradition through the cultivation of a particular religious ethics and aesthetics. Conversely, when the particular religious ethic and aesthetic shape the contours of human relations in a group, a society or a civilization, this group, society and culture must seek constant humanitarian values that make their humanitarian tradition, ready to receive the different. For these reasons religious education is essential in the formation of the elements which compose the human values at the global level. The new religious education through curricula developed by various countries acquires new role and new dimensions, because it adapts to the new social data. This harmonised adjustment is not a denial of local religious traditions, but instead familiarity with them, so that young people realize that first they are people who should face life, themselves, their fellow man and nature with love, affection and confidence. In this new role religious traditions have to offer important lessons and examples dealing with the ways in which mankind develops its creative power. (Perselis, 2013, p. 420) For these reasons the Council of Europe notes: "- Education is essential for combating ignorance, stereotypes and misunderstanding of religions. Governments should also do more to guarantee freedom of conscience and of religious expression, to foster education on religions, to encourage dialogue with and between religions and to promote the cultural and social expression of religions. - School is a major component of education, of forming a critical spirit in future citizens and therefore of intercultural dialogue. It lays the foundations for tolerant behaviour, founded on respect for the dignity of each human being. By teaching children the history and philosophy of the main religions with restraint and objectivity and with respect for the values of the European Convention on Human Rights, it will effectively combat fanaticism. Understanding the history of political conflicts in the name of religion is essential. - Knowledge of religions is an integral part of knowledge of the history of mankind and civilisations. It is altogether distinct from belief in a specific religion and its observance. Even countries where one religion predominates should teach about the origins of all religions rather than favour a single one or encourage proselytising" (Council of Europe, 2005).

I have argued that what the modern school needs today is the presence and enhancement of the lesson of "inter-religious education". This lesson should critically pose those questions relating to religion, without trying to impose any particular version of this. At the same time, beyond the comparative study of different religious traditions, this lesson must seek the wide range of worldview concepts, which extends to the area of anti-religious, atheistic and non-theistic ideas. This doesn't mean that the study of the relationship of a particular religious tradition with the content of a particular cultural construction is abolished. On the contrary, the study of religion in the contemporary school should take heed of all those parameters with which religion is related. Those topics may be the role of Christianity in shaping European cultural identity or the role of Christian denominations to create similar cultural and national perceptions. Specifically, in this way can the role of the Orthodox Christian religion and tradition should be objectively investigated in shaping the Greek culture, the role of protestants in the shaping of American culture, the role of the Buddhist 
religion in the formation of Chinese civilization, the role of Islam in the formation of Arab culture, etc. (Karamouzis, 2012, p. 126).

According to R. Jackson, «The key condition for including religion as a pan-European topic in education was that, despite different views on religion at the personal and societal levels, all could agree that religion is a 'cultural fact' and that knowledge and understanding of religion at this level is highly relevant to good community and personal relations and is therefore a legitimate concern of public policy. This was not a form of intellectual reductionism, but a pragmatic recognition that the fact of the presence of religions in society was the lowest common denominator with which all European states could work in an educational context. Had this strategy not been adopted, the project would not have gone forward» (Jackson, 2010, p. 1133).

In conclusion, we could say that the new curriculum is innovative because it offers all the elements that compose a pluralist and cognitional character, because it considers the demands of the times, the educational needs of modern students, the religious tradition, the other religious traditions, which are not underestimated, but have the same value, according to the new curriculum, with the framework of stable European values, such as democracy, social cohesion, social justice and human rights. Applying modern teaching methods in the new curriculum ensures that religious education in Greek school will provide an upgraded pedagogical function, which will connect meaningfully with the remaining lessons, will be creative and interesting.

\section{References}

Beck, C. (1986). Education for Spirituality. Interchange, 17, 148-156.

Committee of Experts for the Creation of New Curriculum. (2013). Rebuttal of criticism against the new curriculum of Religious in primary school and high school. In The Religious in Contemporary School (pp. 37-58). Athens: Armos, 2013. [in Greek ]

Council of Europe, Parliamentary Assembly, Recommendation 1720. (2005). Retrieved from http://assembly.coe.int/Main.asp?link=/Documents/AdoptedText/ta05/EREC1720.htm

Georgakopoulos, I., Bishop of Dimitriados. (2013). Relations batwing Church and State. In The Religious Education in Contemporary School (pp. 322-332). Athens: Armos, 2013. [in Greek]

Giagkazoglou, S. (2013). The development and pilot implementation of new curriculum of religious in primary school and high school. In The Religious in Contemporary School (pp. 15-34). Athens: Armos. [in Greek ]

Holy Synod of Greek Church, Decision 5 November 2012. (2012). Retrieved from http://www.romfea.gr/epikairotita/14405-2012-11-05-23-11-40 [in Greek]

Jackson, R. (2010). Religious Diversity and Education for Democratic Citizenship: The contribution of the Council of Europe. In International Handbooks of Religion and Education (Vol. 4, pp. 1121-1151). 
Karamouzis, P. (2012). Culture and Interfaith Education. Thesaloniki: Epikentro. [in Greek ]

Karamouzis, P., \& Athanasiadis E. (2011). Religious, Education, Post-modernity. Athens: Kritiki. [in Greek ]

Karamouzis, P. (2009). Religions, Education and democracy the necessity of inter-religious education in the modern public school system. In Politics and Religion - Politologie des religions (vol. III, Serbian, pp. $111-125$ ).

Karamouzis, P. (2008). Religious Education, National Tradition and Multicultural Societies. The necessity of Multi-Religious Education in the Modern Greek Society. Pedagogikos Logos, 1, 67-76.

Katz, E., \& Levin, M., \& Hamilton, H. (1963). Traditions of research on the diffusion of innovation. American Sociological Review, 28(2), 237-252.

Ministry of Education, Circular 104071/C2//04/08/2008. (2008). Retrieved from http://users.sch.gr/polstrantz/4808.pdf [in Greek ]

Ministry of Education, Circular 56664/IH/25-06-2010. (2010). Retrieved from http://edu.klimaka.gr/leitoyrgia-sxoleivn/anakoinvseis/884-apallagh-apo-to-mathhma-twn-thr hskevtikwn.html [in Greek ]

Ministry of Education. (2011). Curriculum in Religious Education. [in Greek ]

Paparizos, A. (2011). God, authority and religious consciousness. Athens: Papazisis. [in Greek ]

Perselis, E. (2013). The European orientation of the religious lesson. Findings and perspective, in The Religious in Contemporary School (pp. 415-428). Athens: Armos. [in Greek]

Stauning-Willert, T., \& Molokotos-Liederman, L. (2012). How can we speak of innovation in the Greek Orthodox Tradition? Towards a typology of innovation in religion. In Innovation in the Orthodox Christian Tradition? The Question of Change in Greek Orthodox Thought and Practice (pp. 3-17). Great Britain: Asgate.

\section{Copyright Disclaimer}

Copyright reserved by the author(s).

This article is an open-access article distributed under the terms and conditions of the Creative Commons Attribution license (http://creativecommons.org/licenses/by/3.0/). 